\title{
ENGINEERING PARAMETERS AFFECTING THE PERFORMANCE OF MEAT GRINDER
}

\author{
Awdallah, Y. S. ${ }^{1}$ and K. I. Wasfy ${ }^{1}$
}

ABSTRACT

Experiments were carried out to study different engineering parameters affecting the performance of camel meat grinder in order to increase product quality and decrease both energy and cost. The grinder shaft was designed so as to save it from over loads and high stresses. The grinder performance was studied as a function of change in meat mass (250, 450, 650 and $850 \mathrm{~g}$ ), rotational speed (200,250, 300 and $380 \mathrm{rpm})$, die holes diameter (4 and 6mm) and number of blades (4, 6 and 8 blades). Performance was evaluated was in terms of water holding capacity, grinder productivity, required power, energy requirements and grinding cost.

The experimental results reveal that the grinder performance was in the optimum region under the following conditions:

- The grinder shaft must be designed at a $25 \mathrm{~mm}$ diameter.

- Operate the grinder at a rotational speed of $300 \mathrm{rpm}(0.39 \mathrm{~m} / \mathrm{s})$.

- The extruding plate was to be $6 \mathrm{~mm}$ die hole diameter.

- $\quad$ The meat mass should be ranged from $450 \mathrm{~g}$ to $650 \mathrm{~g}$.

- Using 6 blades in the meat grinder.

\section{INTRODUCTION}

eat is one of the most essential nutritious food item that
needed for human consumption from which high quality
proteins, minerals and essential vitamins. Camels are one of the most fundamental pillars of the national economy and food security for many countries in the world, because it occupies a very important role in providing an important part of human food, especially meat, in order to fulfill the shortfall in the increasing demand for meat due to the rapid growth of human population and the increase of the demand for the food stuffs. It produces a large quantities of meat compared to other farm animals, where the weight of a camel is of between 350 to $700 \mathrm{~kg}$ and the

\section{${ }^{1}$ Lecturer of Agric. Eng., Fac. of Agric., Zagazig Univ.}


proportion of camel net meat is high as it varies by different factors such as age, type of nutrition and type of breeding, ranging from 43.6 to $62.7 \%$ and the proportion of fat and bones are zero to $4.8 \%$ and 15.9 to $38.1 \%$, respectively. Camel meat is known for its large muscular fibers and high percentage of water. It is also a good source of many vitamins, especially vitamin B complex and important minerals such as iron, calcium and phosphorus. According to FAO statistics (2012), the production quantity of camel meat in Egypt has reached to be about 47250 tons. The demand for camel meat appears to be increasing due to health reasons, as they produce carcasses with less fat as well as having less cholesterol and relatively high polyunsaturated fatty acids than other meat animals. Studies and medical research have proved that camel meat is superior to other kinds of meat. Grinding is one of the main methods of precision manufacturing and the process quality. A meat grinder is a machine used to force meat or meat trimmings by means of a feeding worm (auger) under pressure through a horizontally mounted cylinder (barrel). At the end of the barrel there is a cutting system consisting of star-shaped knives rotating with the feeding worm and stationary perforated discs (grinding plates). Soliman and Abd El-Maksoud (2001) studied the effect of meat chopper capacity, fat percentage and meat-piece size as operational parameters on power requirements, energy consumption per unit weight, meat temperature and chopping quality (meat particles diameter and density) of choppers during 40 seconds of chopping operation. The chopping net power per unit weight ranged from 1.5 to $4.5 \mathrm{~kW} / \mathrm{kg}$. Tests indicated that during the first five seconds, the power was directly proportional with all of the operational parameters. The specific energy consumption during the first five seconds ranged from 8 to $17 \mathrm{~kJ} / \mathrm{kg}$. The mechanical energy loss by friction, which is converted to heat, was determined based on temperature measurements. The frictional energy loss were found to be at least $60 \%$ of the total energy consumption by the sample during the first five seconds and then increased. Kitun and Perednya (2006) stated that the easiest way to improve the degree of grinding of feeds without altering the construction of the grinding machine is to reduce the clearance between the tips of the grinder blades and the interior surface of the grinding chamber. Studies have shown that 
these conditions increase the friction between the feed and the chamber's interior surface, thus increasing the specific energy consumption of the grinding process. Application of the findings showed that for grinder ISK3 , the optimal clearance between the interior of the grinding chamber and the ends of the blades was $12 \mathrm{~mm}$. Tkacz (2007) studied energetistic aspect of grinding meat using grinder plates $(4 \mathrm{~mm}$ and $10 \mathrm{~mm}$ ). The results showed that the highest values of active power grinding beef meat class (II) was characterized at $256 \mathrm{~kW}(4 \mathrm{~mm}) ; 135 \mathrm{~kW}(10 \mathrm{~mm})$, whereas the lowest values noted during grinding beef class (I) $152 \mathrm{~kW}$ (4 $\mathrm{mm}) ; 046 \mathrm{~kW}(10 \mathrm{~mm})$. During grinding, the meat was influenced by the class of meat on the total electric energy consumption. Schnackel $\boldsymbol{e t}$ al. (2011) stated that one of the most important operations for production of a lot of meat products is the necessary size reduction especially in meat mincers. Mincing machines work by the principle of rotating shear process. The meat is sheared between the edge of the knife and the holes of the plate. The results of the plate knife system show that compression and friction are increasing with increasing both of pressure and diameter of drill holes in the plate. For the strain energy, an increase with increasing pressure and a decrease with increasing diameter of drill holes was found. The results showed that the relative amount of disintegration work was increasing with decreasing pressure. That means the best "quality of shearing" can be found for lower pressure. Krickmeier et al. (2012) mentioned the characterization of the necessary cutting works compression, friction, disintegration and shift in dependence of machinery and raw material influences (cutting speed, pressure, drill hole diameter, animal species, type of tissue, temperature, fiber orientation and sample size). Because of the amount of compression and destruction increase at higher cutting speed and the energy consumption of the meat grinder will increase, too. By use of adapted drill hole diameter on raw material commination, the energy consumption decreases, which means a smaller sample size and a higher drill hole diameter reduce the strain energy and support the raw material flow. On low level of grinding pressure works for friction, compression and strain energy are reduced as well as raw material strain and quality losses. Irmscher et al. (2013) evaluated the influence of process conditions (knife geometry, volume 
flow rate, and bulk mass temperature) on structure, physicochemical properties and sensory performance of fermented coarse meat emulsions (aka salami). Salamis (65\% lean pork meat, 35\% pork belly) were prepared by passing mixtures through knife-plate assemblies with varying knife blade numbers (6 to10). Bulk mass temperature prior to processing was varied between $\left(-3\right.$ and $\left.+2^{\circ} \mathrm{C}\right)$. Energy consumption was reduced by $25 \%$ (eight blades) and 20\% (10 blades) relative to six blades per knife. An increase of volume flow rate from 46 to $97 \mathrm{~L} / \mathrm{min}$ had no negative effects on product appearance. Warmer raw material decreased energy consumption by $40 \%$.

This research is aimed to improve the products quality with less energy consumption through studying the effect of some different engineering parameters (sample masses, rotational speeds, drill holes diameter and number of blades) on the performance of the meat grinder and its impact on economic point of view.

\section{MATERIALS AND METHODS}

Experiments were carried out through the year of 2016 at a private butcher store of Belbeis, Sharqia Governorate, Egypt in order to optimize the specific energy by minimizing the friction force.

\section{Materials}

\subsection{Meat}

The raw material pieces were taken from round location of camel with an age of about 5 years old. Some physical and mechanical properties were determined as shown in Table (1).

Table (1): Some physical, mechanical and chemical properties of the used camel meat

\begin{tabular}{|c|c|c|c|}
\hline \multirow{2}{*}{$\begin{array}{c}\text { Physical } \\
\text { properties }\end{array}$} & Density, $\mathrm{g} / \mathrm{cm}^{3}$ & Moisture content, \% & Meat temperature, ${ }^{\circ} \mathrm{C}$ \\
\hline & 1.11 & 78.7 & 17 \\
\hline \multirow{2}{*}{$\begin{array}{c}\text { Mechanical } \\
\text { properties }\end{array}$} & \multicolumn{2}{|c|}{ Coefficient of friction } & Friction angle, degree \\
\hline & \multicolumn{2}{|c|}{0.25} & 14 \\
\hline \multirow{2}{*}{$\begin{array}{l}\text { Chemical } \\
\text { properties }\end{array}$} & Fat, \% & Protein, $\%$ & $\%$ \\
\hline & 1.15 & 21.83 & 5.8 \\
\hline
\end{tabular}

Determination of moisture, ash, protein and fat (ether extract) were performed according to AOAC (1990) methods. Moisture content was measured used an air oven technique at $102 \pm 2^{\circ} \mathrm{C}$ for $18 \mathrm{hs}$ in three 
replicates of about $5 \mathrm{~g}$ per each.

\subsection{Grinder}

The grinder, as shown in Fig. 1 is used to force meat by means of rotating shaft to pass under pressure through a horizontal mounted cylinder (shaft housing). The clearance between the shaft and housing was $4 \mathrm{~mm}$. At the end of the shaft housing there is a cutting system consisting of a crossshaped knives rotating with the shaft and a stationary perforated disc (hole plate). Two types of disc plates were used under study with diameter of $100 \mathrm{~mm}$, one of them was of $6 \mathrm{~mm}$ die hole diameter (No. of holes $=24$ ) and the other was $4 \mathrm{~mm}$ die hole diameter (No. of holes $=56$ ). The meat is compressed by the rotating shaft of feeding auger, pushed through the cutting system and extrudes through the holes in the grinding hole plates after being cut by the revolving star knives. The degree of grinding is determined by the size of the holes in the hole plate. It was driven by an electrical motor of $2 \mathrm{hp}(1.47 \mathrm{~kW})$. Pulley and belts were used as a transmission system between motor and rotating shaft to obtain the required reduction percentage. Drive pulleys were 80 and $100 \mathrm{~mm}$ diameters that transmitted the motion to the driven pulleys on the rotating shaft which had diameters of 370 and $560 \mathrm{~mm}$.

\section{Methods}

\subsection{Design of grinder shaft}

The grinder shaft is supported by two bearings. A belt of V-shape is fixed on the pulley in the end of the shaft to transport load $\left(\mathrm{T}_{\mathrm{D}}\right)$. Another distributed load due to shaft mass and meat mass is applied to the same shaft to be $139 \mathrm{~N} / \mathrm{m}$.

To calculate the belt tension $\mathrm{T}_{1}$ and $\mathrm{T}_{2}$ :

Mass/unit length of belt $(\mathrm{m})$ was calculated using the following equation: $m=\rho A$

$\rho$ : Density of belt, $\left(980 \mathrm{~kg} / \mathrm{m}^{3}\right) . \quad$ A: Cross-sectional area of belt, $\mathrm{m}^{2}$

Type of V-belt with a power range of 0.7-3.5 KW, a top width (b) of 13 $\mathrm{mm}$, (a) of $7.18 \mathrm{~mm}$ and thickness (c) of $8 \mathrm{~mm}$ is selected.

$A=\frac{1}{2}(a+b) c=\frac{1}{2}(7.18+13) \frac{8}{10^{6}}=80.72 \times 10^{-6} \mathrm{~m}^{2}$

$m=\rho A=980 \times\left(80.72 \times 10^{-6}\right)=0.79 \mathrm{~kg} / \mathrm{m}$

Peripheral Velocity $(V)$ :

$$
V=w R
$$




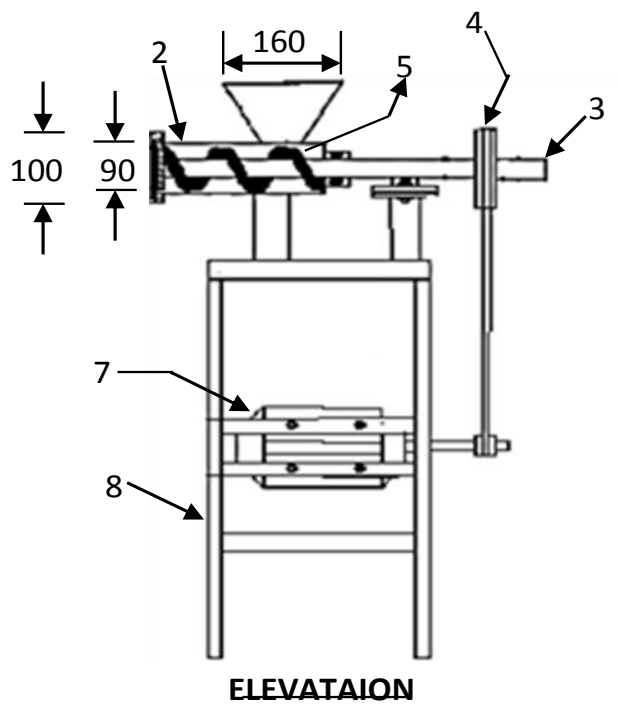

All dimensions in $\mathrm{mm}$.

1. Grinder hopper

2. Grinder housing

3. Rotating shaft

4. Pulley and belt

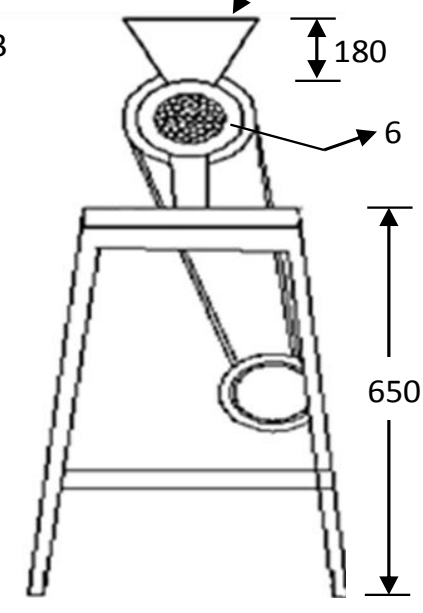

SIDE VIEW

\section{Fig.1. Meat grinder}

r: Radius of smaller pulley on motor shaft $(0.05 \mathrm{~m})$.

$\mathrm{R}$ : Radius of larger pulley on shaft housing $(0.275 \mathrm{~m})$.

$\mathrm{N}_{1}$ : Rotational speed of electric motor (1420 rpm).

$\mathrm{N}_{2}$ : Rotational speed of grinder shaft.

$N_{2}=\frac{N_{1} d}{D}=\frac{1420 \times 10}{55}=258.18 \mathrm{rpm}$

$\omega=\frac{2 \pi N_{2}}{60}=\frac{2 \pi \times 258.18}{60}=27.04 \mathrm{rad} / \mathrm{s}$

$v=27.04 \times 0.275=7.44 \mathrm{~m} / \mathrm{s}$

Centrifugal Tension:

$T c=m V^{2}$

$\mathrm{T}_{\mathrm{c}}=0.79 \times(7.44)^{2}=43.73 \mathrm{~N}$

$\frac{T_{1}-T_{C}}{T_{2}-T_{C}}=e^{\left.\frac{R\left(\frac{R \alpha}{2}\right)}{2}\right)}$

Scale 1:1

5. Screw auger

6. Die hole plate

7. Electric motor

8. Grinder trestle

$\alpha$ : Angle of wrap for smaller pulley, rad

$\theta=$ Groove angle for $\mathrm{V}$-belt $=30^{\circ}$

$\alpha=180^{\circ}-2 \sin ^{-1}\left(\frac{R-r}{\circ}\right)$

c: Center distance between pulley $=0.5 \mathrm{~m}$ 


$$
\begin{aligned}
& \alpha=180^{\circ}-2 \sin ^{-1}\left(\frac{0.275-0.05}{0.5}\right)=126.51^{\circ}=2.21 \mathrm{rad} \\
& \frac{T_{1}-43.73}{T_{2}-43.73}=e^{\frac{0.275 \times 2.21}{(\sin 30) / 2}}=e^{2.43}=11.36 \\
& T_{1}=11.36 T_{2}-453.04
\end{aligned}
$$

Torque supplied $\left(\mathrm{T}_{\mathrm{t}}\right)$ from $\mathrm{p}$ and $\left(\mathrm{N}_{2}\right)$ rpm of shaft housing:

$T_{t}=\frac{p}{w}$

$P$ : Power transmitted by electric motor (2hp).

$T_{t}=\frac{2 \times 1000}{1.36 \times 27.04}=54.39 \mathrm{N.m}$

$\mathrm{T}_{\mathrm{t}}=\left(\mathrm{T}_{1}-\mathrm{T}_{2}\right) \times \mathrm{R}$

$\mathrm{T}_{1}-\mathrm{T}_{2}=197.78$

Substituting equation (6) into (9):

$T_{1}=260.60 \mathrm{N.m}$

$$
T_{2}=62.82 \mathrm{~N} \cdot \mathrm{m}
$$

The loads acting on the shaft and pulley (D) are shown in Fig. 2:

$\mathrm{M}_{\mathrm{k}}$ : Weight of the knife $(1.1 \mathrm{~N})$ at A.

$\mathrm{U}_{\mathrm{L}}$ : Uniform distributed load $(139 \mathrm{~N} / \mathrm{M})$.

$\mathrm{W}$ : The weight of the pulley $(28 \mathrm{~N})$

$\mathrm{R}_{\mathrm{B}}=$ Reaction of the bearing at $\mathrm{B} . \quad \mathrm{R}_{\mathrm{C}}=$ Reaction of the bearing at $\mathrm{C}$.

$\mathrm{T}_{\mathrm{D}}=\mathrm{T}_{1}+\mathrm{T}_{2}=260.60+62.82=323.42 \mathrm{~N} . \mathrm{m}$

Vertical loading at the pulley $\mathrm{D}\left(\mathrm{F}_{\mathrm{DV}}\right)$ :

$\mathrm{T}_{\mathrm{DV}}=\mathrm{T}_{\mathrm{D}} \sin 60=323.42 \sin 60=280.09 \mathrm{~N}$

$\mathrm{F}_{\mathrm{DV}}=\mathrm{T}_{\mathrm{D}} \sin 60+\mathrm{W}_{\mathrm{D}}=280.09+28=308.09 \mathrm{~N} \sim 308 \mathrm{~N}$

Horizontal loading at the pulley $\mathrm{D}\left(\mathrm{F}_{\mathrm{DH}}\right)$ :

$\mathrm{F}_{\mathrm{DH}}=\mathrm{T}_{\mathrm{DH}}=\mathrm{T}_{\mathrm{D}} \cos 60=323.42 \cos 60=161.71 \mathrm{~N} \sim 162 \mathrm{~N}$

Determination of reactions:

Reactions on vertical direction:

$\sum \mathrm{M}_{\mathrm{B}}=0$

$-(1.1 \times 0.23)-(31.97 \times 0.115)-\left(\mathrm{R}_{\mathrm{C}} \times 0.1\right)+(308 \times 0.2)=0$

$\mathrm{R}_{\mathrm{C}}=576.70 \mathrm{~N}$

$\sum \mathrm{M}_{\mathrm{C}}=0$

$-(1.1 \times 0.33)-(31.97 \times 0.215)-\left(\mathrm{R}_{\mathrm{B}} \times 0.1\right)+(308 \times 0.1)=0$

$\mathrm{R}_{\mathrm{B}}=235.63 \mathrm{~N}$

Reactions on horizontal direction:

$\sum \mathrm{M}_{\mathrm{B}}=0$

$-\left(\mathrm{R}_{\mathrm{C}} \times 0.1\right)+(162 \times 0.2)=0$

$\mathrm{R}_{\mathrm{C}}=324 \mathrm{~N}$

$\sum \mathrm{M}_{\mathrm{C}}=0$

$-\left(\mathrm{R}_{\mathrm{B}} \times 0.1\right)+(162 \times 0.1)=0$

$$
\mathrm{R}_{\mathrm{B}}=162 \mathrm{~N}
$$


PROCESS ENGINEERING

Determination of maximum bending moment:

Moments at vertical direction:

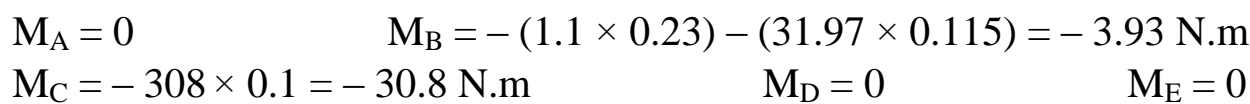

Moments at horizontal direction:

$\mathrm{M}_{\mathrm{A}}=0$

$\mathrm{M}_{\mathrm{B}}=0$

$\mathrm{M}_{\mathrm{C}}=-162 \times 0.1=-1602 \mathrm{~N} \cdot \mathrm{m}$

$\mathrm{M}_{\mathrm{D}}=0$

$\mathrm{M}_{\mathrm{E}}=0$

The resultant bending moment at $\mathrm{B}$ :

$\mathrm{M}_{\mathrm{B}}=3.93 \mathrm{~N} \cdot \mathrm{m}(-)$

The resultant bending moment at $\mathrm{C}$ :

$M_{C}=\sqrt{M_{C V}{ }^{2}+M_{C H}{ }^{2}}=\sqrt{(30.8)^{2}+(16.2)^{2}}=34.8$ N.m $(-)$

$\mathrm{M}_{\max }=34.8 \mathrm{~N} . \mathrm{m}$

Determination of the shaft diameter using maximum shear theory

To calculate the shaft diameter $\mathrm{d}_{\mathrm{o}}$ :

In actual practice shafts are subjected to torque and bending moment. For shafts subjected to combine bending and torsion, the shaft diameter $\mathrm{d}_{0}$ is given by:

$\tau_{\max }=\frac{16}{\pi d^{3}} \sqrt{\left(K_{b} M_{\max }\right)^{2}+\left(K_{t} T_{t}\right)^{2}}$

$\mathrm{K}_{\mathrm{b}}$ and $\mathrm{K}_{\mathrm{t}}$ are combine shock and fatigue factors for bending and torsion. The recommended value for $\mathrm{Kb}$ and $\mathrm{Kt}$ are 1.5 and 1.0 for steady loading (Khurmi, 2005).

Maximum allowable stress in shaft $\left(\tau_{\max }\right)=30 \times 10^{5} \mathrm{~N} / \mathrm{m}^{2}$

$30000000=\frac{16}{\pi d^{s}} \sqrt{(1.5 \times 34.8)^{2}+(1.0 \times 54.39)^{2}}$

$$
\mathrm{d}=23.39 \mathrm{~mm}
$$

So, the grinder shaft is designed at a $25 \mathrm{~mm}$ diamter.

\subsection{Experimental Conditions}

The performance of the grinder was experimentally measured under the following parameters:

- Four rotational shaft speeds $(200,250,300$ and $380 \mathrm{rpm})$, corresponded to $(0.26,0.33,0.39$ and $0.50 \mathrm{~m} / \mathrm{s}$, respectively) peripheral speeds.

- Four meat-piece masses (250, 450, 650 and $850 \mathrm{~g})$.

- Two die holes diameters (4 and $6 \mathrm{~mm}$ ). 


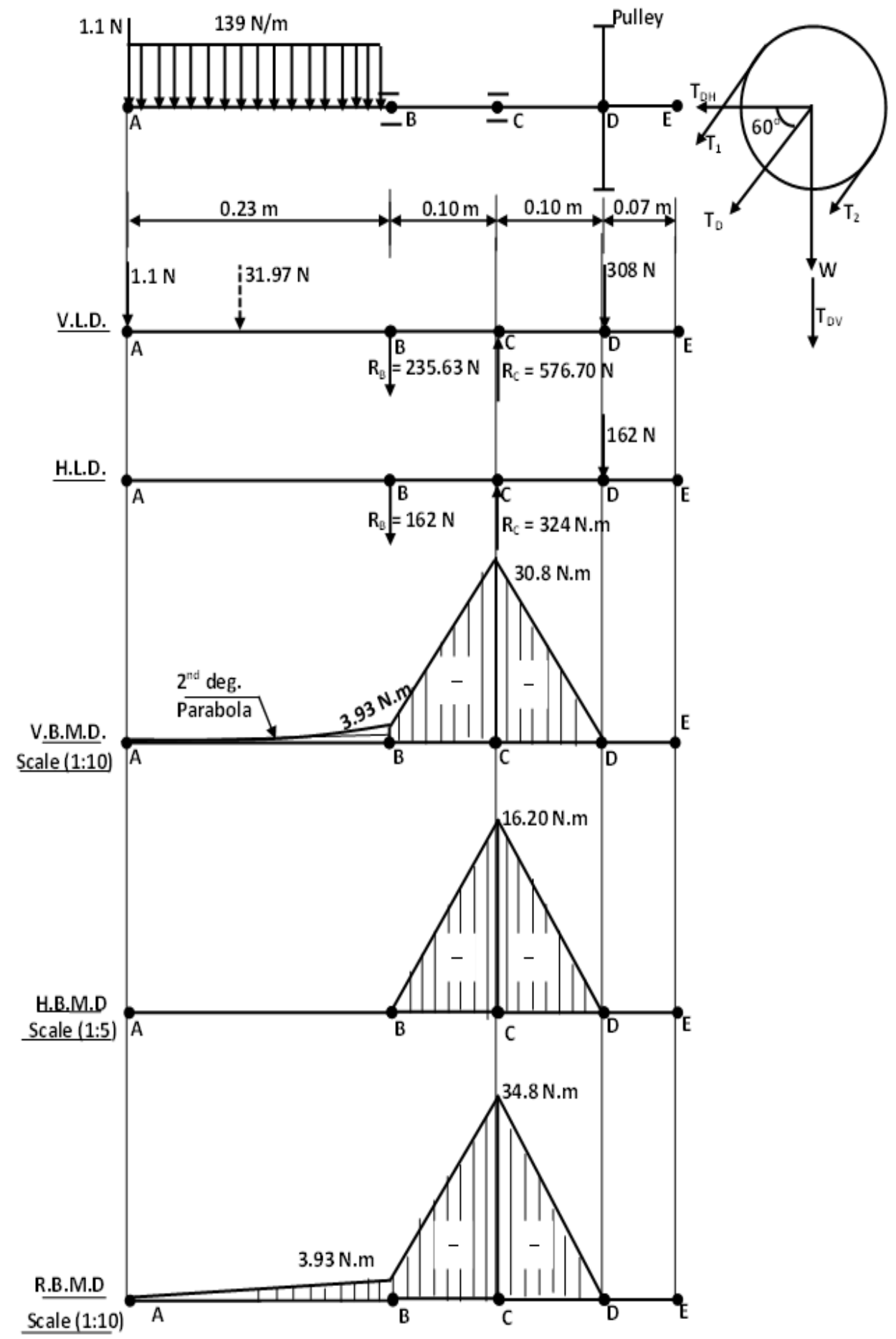

Fig. 2. Bending moment diagram of the grinder shaft 
- Three number of blades (4, 6 and 8 blades).

The meat pieces were prepared by cutting the meat into about equal small samples to be used in the experiments. Duration times for each treatment were measured using stopwatch.

\subsection{Measurements and Determinations}

Evaluation of the grinder performance was based on the following indicators:

\subsubsection{Water holding capacity (Quality characteristic)}

Water holding capacity (WHC) was determined according to (Grau, 1960) by weigh approximately $300 \mathrm{mg}$ of homogenized meat on a plastic foil. Put a rectangle of filter paper $(100 \times 100 \mathrm{~mm})$ on a glass board and face the plastic foil with the meat sample to the paper. Cover the foil with another glass board and weight down with a $1 \mathrm{~kg}$ weight for exactly 5 minutes. Then take the set apart and measure the areas of pressed stains. The actual determination of the areas can be done by planimeter and calculated by the following equation:

$\operatorname{WHC}(\%)=100-\left(A_{1} / A_{2}\right)$

Where: $A_{1}$ : Area of pressed meat; $A_{2}$ : Area of stain.

\subsubsection{Grinder productivity}

Productivity $\left(M_{p}\right)$ was determined by the following equation:

$M_{p}(\mathrm{~kg} / \mathrm{h})=W_{s} / t$

Where: $\mathrm{W}_{\mathrm{S}}$ : Mass of meat sample collected from the out let, $\mathrm{kg}$;

$\mathrm{t}$ : The consumed time of the grinding, $\mathrm{h}$.

\subsubsection{Required power}

The following formula was used to estimate the required power (Kurt, 1979):

$P=(I \times V) / 1000$

Where: $P$ : Required power, $\mathrm{kW}$;

$$
\text { I: Current intensity, Ampere; } \quad V \text { : Voltage }(220 \mathrm{~V}) .
$$

\subsubsection{Energy requirements}

The energy requirements for the grinding process can be calculated as follows:

$$
\text { Energy requiremen ts }(\mathrm{kW} . \mathrm{h} / \mathrm{Mg})=\frac{\text { Required power }}{\text { Grinder productivi ty }}
$$

\subsubsection{Grinding cost}

The grinder hourly cost was determined by using the following equation 
PROCESS ENGINEERING

(Awady et al. 1978):

$\mathrm{C}=\frac{\mathrm{p}}{\mathrm{h}}\left(\frac{1}{\mathrm{a}}+\frac{\mathrm{i}}{2}+\mathrm{t}+\mathrm{r}\right)+(\mathrm{W} \cdot \mathrm{e})+\frac{\mathrm{m}}{144}$

Where:

C: Grinder hourly cost, L.E./h $\quad$ P: Price of grinder, L.E.

h: Yearly working hours, h/year i: Annual interest rate, $\%$

a: Life expectancy of the machine, year t: Taxes and over heads ratio, $\%$

r: Annual repairs and maintenance ratio, $\% \quad \mathrm{~W}$ :Power of motor, $\mathrm{kW}$

e: Hourly cost, L.E/kW.h m: The monthly average wage, L.E./month 144: Reasonable estimation of monthly working hours.

The grinding cost was calculated by the following equation as:

Grinding cost (L.E./Mg) $=\frac{\text { Grinder hourly cost }}{\text { Grinder productivi ty }}$

\section{RESULTS AND DISCUSSION}

The discussion will cover the obtained results under the following heads:

\section{Water holding capacity (WHC)}

Water holding capacity (WHC) of muscle is an important parameter because it affects both qualitative and quantitative aspects of meat products. It is the ability of meat to hold this specific water to ensure the stability of meat products and limit drip loss during storage. Fig. 3 shows the effect of rotational speed, meat mass and number of holes on water holding capacity under die hole diameters of 4 and $6 \mathrm{~mm}$.

Regarding to the effect of rotational speed on WHC at mass of $450 \mathrm{~g}$ and number of blades 4 , results showed that increasing rotational speed from 200 to $380 \mathrm{rpm}$ was followed with a decrease in the WHC from 87.5 to 76 $\%$ and from 90 to $79 \%$ at $4 \mathrm{~mm}$ and $6 \mathrm{~mm}$ die hole diameters, respectively. This may be due to tearing of the tissues; particles diminish in size and increases total surface area causing less water holding capacity with increasing rotational speed. This is a compatible with Soliman and Abd El-Maksoud (2001).

With respect to the effect of using different meat masses at $250 \mathrm{rpm}$ and 4 blades, obtained data clarified that WHC was increased by increasing meat masses. At $450 \mathrm{~g}$, WHC values were 83 and $86 \%$ under die hole diameters of 4 and $6 \mathrm{~mm}$, respectively.

Concerning the effect of number of blades on WHC at rotational speed of 


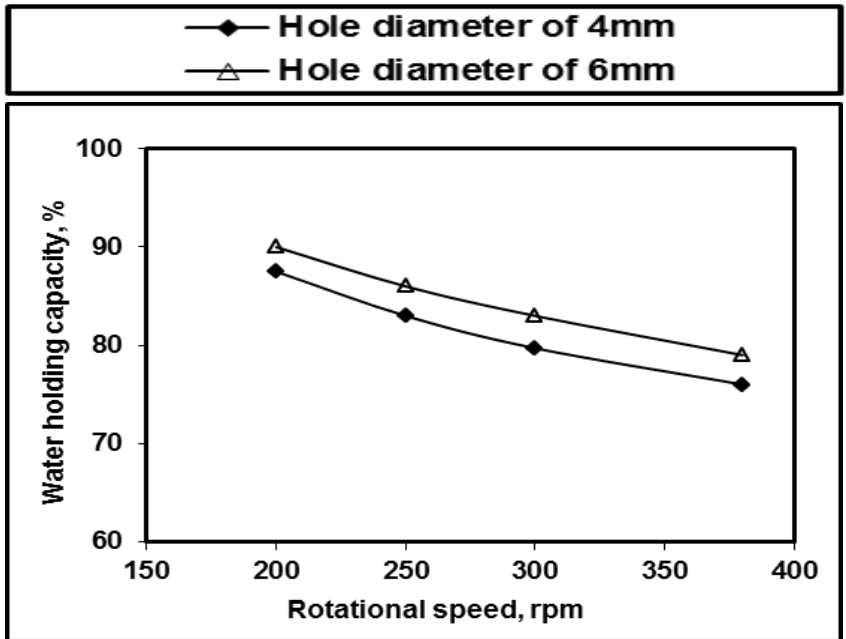

(A) At constant: Meat mass of $450 \mathrm{~g}$ and 4 blades

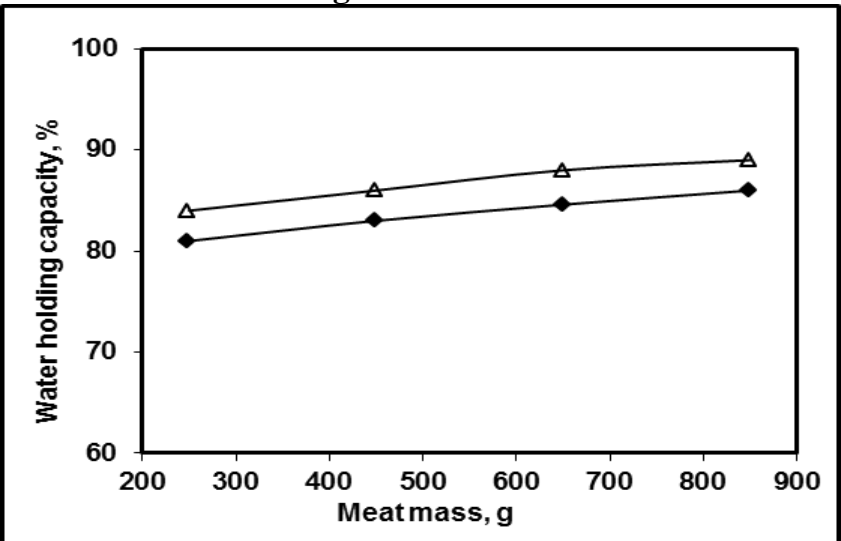

(B) At constant: Rotational speed of $250 \mathrm{rpm}$ and 4 blades

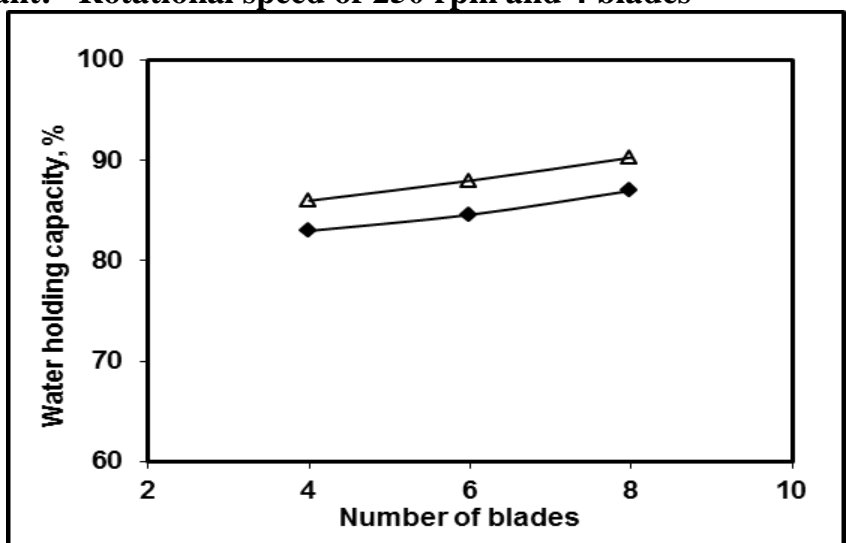

(C) At constant: Rotational speed of $250 \mathrm{rpm}$ and $450 \mathrm{~g}$ meat mass

Fig. 3. Effect of rotational speed, meat mass and number of blades on water holding capacity under different holes diameter 
$250 \mathrm{rpm}$ and $450 \mathrm{~g}$ meat mass, results revealed that the WHC was increased by increasing number of blades. By using 4 to 8 blades, it was increased from 83 to $87 \%$ and from 86 to $90.3 \%$ for $4 \mathrm{~mm}$ and $6 \mathrm{~mm}$ hole diameters, in that order. That may be due to the texture become increasingly less firm by increasing the number of blades, leading to an increase in WHC.

The use of $4 \mathrm{~mm}$ die hole diameter, the stresses that exerted in a meat grinding process increased which diminish product quality according to (Haack and Schnaeckel, 2008). Added to that the decrease in the particles mean diameter, causing an increase in the projected area of mass transport of water and thus the WHD was decreased compared with $6 \mathrm{~mm}$ die hole diameter.

\section{Grinder productivity}

Influence of different parameters on the grinder productivity is illustrated in Fig. 4.

Regarding the effect of rotational speed, results indicated that the productivity was increased by increasing rotational speed up to $300 \mathrm{rpm}$ and then decreased. At highest speed, coefficient of friction was increased, complete rupture of meat tissues, squeezing meat, impeded the conveying process and thereby, decrease in the materials flow and productivity. The lowest values of productivity were 73 and $77 \mathrm{~kg} / \mathrm{h}$ at $200 \mathrm{rpm}$ rotational speed, $450 \mathrm{~g}$ meat mass and 4 number of blades under 4 and $6 \mathrm{~mm}$ hole diameters, respectively.

Productivity was increased with respect to the effect of increasing meat mass under rotational speed of $250 \mathrm{rpm}$ and 4 blades. It was $75,81,89$ and $100 \mathrm{~kg} / \mathrm{h}$ for $4 \mathrm{~mm}$ hole diameter and 80, 87, 96 and $107 \mathrm{~kg} / \mathrm{h}$ for 6 $\mathrm{mm}$ hole diameter under meat masses of $250,450,650$ and $850 \mathrm{~g}$, in that order. Grinding duration time was varied with different meat masses.

It was observed from results that the increase of blades number from 4 to 8 blades at rotational speed of $250 \mathrm{rpm}$ and $450 \mathrm{~g}$ meat mass, the productivity was decreased. Increasing the number of blades impeded the conveying process by blocking more bore holes (Haack and Schnaeckel, 2008). Added to that increasing blade numbers, the area through which the material can flow decreased and thereby, the productivity was decreased, this is a compatible with Irmscher et al. (2013). The highest 


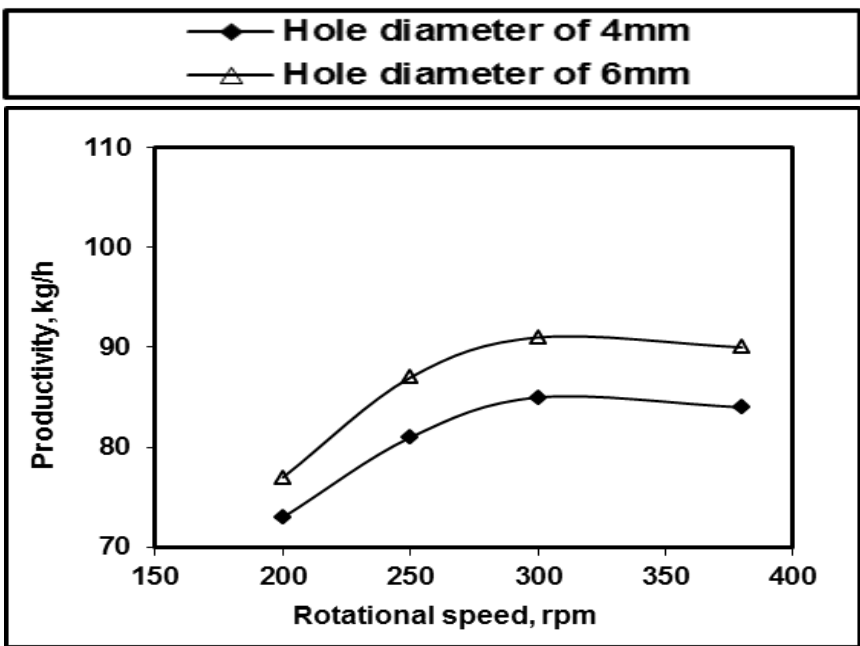

(A) At constant: Meat mass of $450 \mathrm{~g}$ and 4 blades

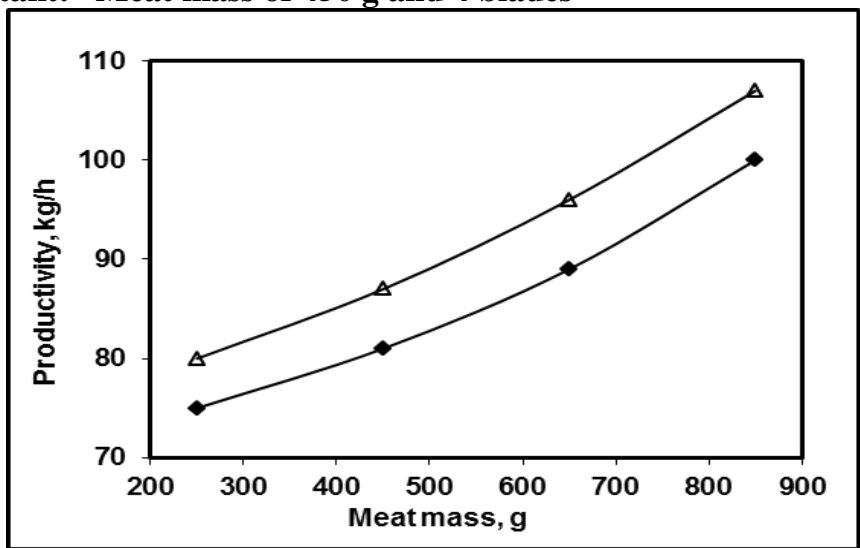

(B) At constant: Rotational speed of $250 \mathrm{rpm}$ and 4 blades

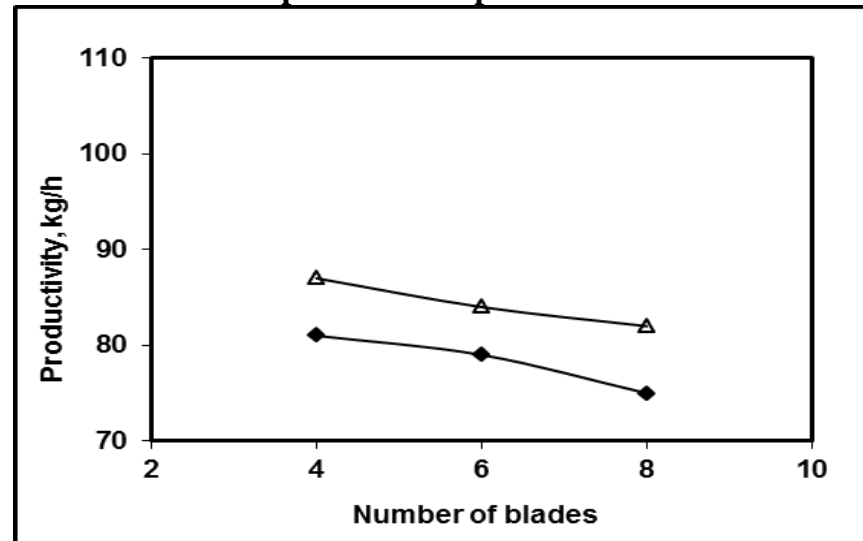

(C) At constant: Rotational speed of $250 \mathrm{rpm}$ and $450 \mathrm{~g}$ meat mass

Fig. 4. Effect of rotational speed, meat mass and number of blades on meat grinder productivity under different holes diameter 
values were $81 \mathrm{~kg} / \mathrm{h}$ and $87 \mathrm{~kg} / \mathrm{h}$ for die hole diameters of 4 and $6 \mathrm{~mm}$, respectively under using 4 blades.

At die hole diameter of $6 \mathrm{~mm}$, the productivity was increased comparing with using die hole diameter of $4 \mathrm{~mm}$ due to the flow of material was increased by increasing the hole diameters.

\section{Required power}

The effect of different parameters on the performance of meat grinder related to required power were illustrated in Fig. 5.

It was noticed that the required power was increased by increasing rotational speed under meat mass of $450 \mathrm{~g}$ and using 4 blades. Using the highest rotational speed of $380 \mathrm{rpm}$ was accompanied with an increase in the required power by 14.58 and $18.68 \%$ compared to $200 \mathrm{rpm}$ under hole diameters of 4 and $6 \mathrm{~mm}$ die hole diameters, respectively. This is attributed to complete rapture for meat tissues, particles diminish in size and increase in the friction resistance which reflected on more required power. This is in agreement with Soliman and Abd El-Maksoud (2001). In relation to different meat masses effect, obtained data explained that increase the required power with increasing meat mass. It was 1.01, 1.04, 1.09 and $1.13 \mathrm{~kW}$ for $4 \mathrm{~mm}$ die hole diameter, while $0.99,1.01,1.07$ and $1.09 \mathrm{~kW}$ for $6 \mathrm{~mm}$ die hole diameter under $250 \mathrm{rpm}$ rotational speed and 4 blades for 250, 450,650, $850 \mathrm{~g}$, respectively. The masses pieces were proportional to time duration and the required power added to that the high quantity of samples consumed high rates of required power in cutting meat pieces.

Regarding to the effect of number of blades on the required power, results showed that power was decreased with increasing blades from 4 to 8 under rotational speed of $250 \mathrm{rpm}$ and $450 \mathrm{~g}$ meat mass. The required power values were 0.98 and $0.92 \mathrm{~kW}$ using 6 blades for hole diameters of 4 and $6 \mathrm{~mm}$, respectively.

With respect to die hole diameters effects on the required power. It was clear that the power was at lower values by using $6 \mathrm{~mm}$ hole diameter as compared to $4 \mathrm{~mm}$ die hole diameter. the reason of that may be returned to that the decrease in the diameter per unit area, increase the exerted stresses and friction in grinding process which reflected to an increase in 


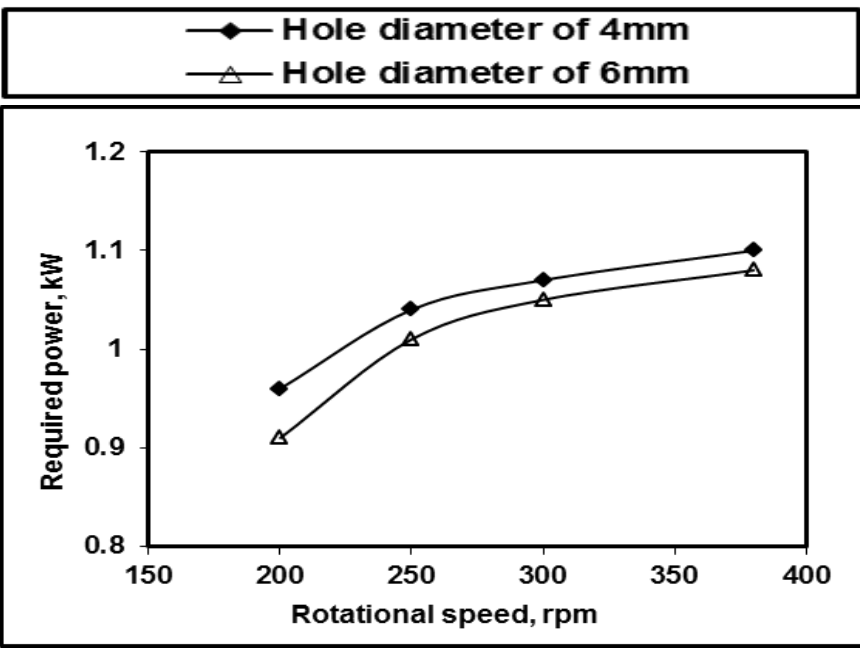

(A) At constant: Meat mass of $450 \mathrm{~g}$ and 4 blades

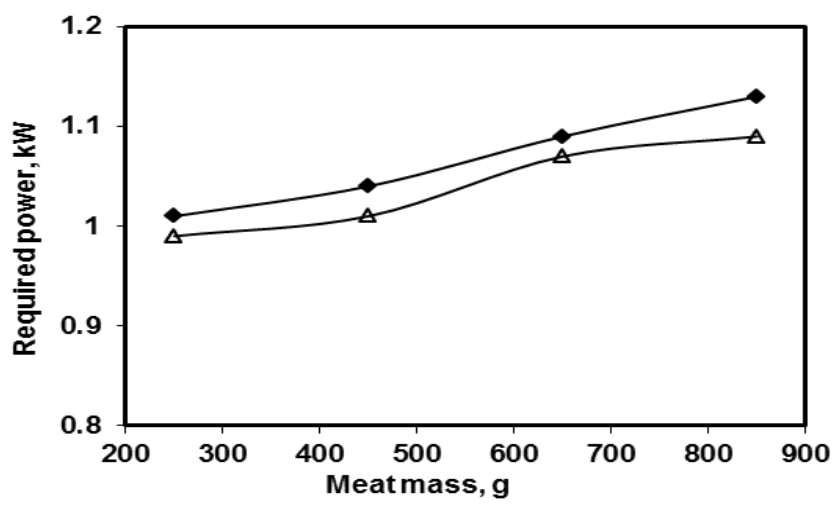

(B) At constant: Rotational speed of $250 \mathrm{rpm}$ and 4 blades

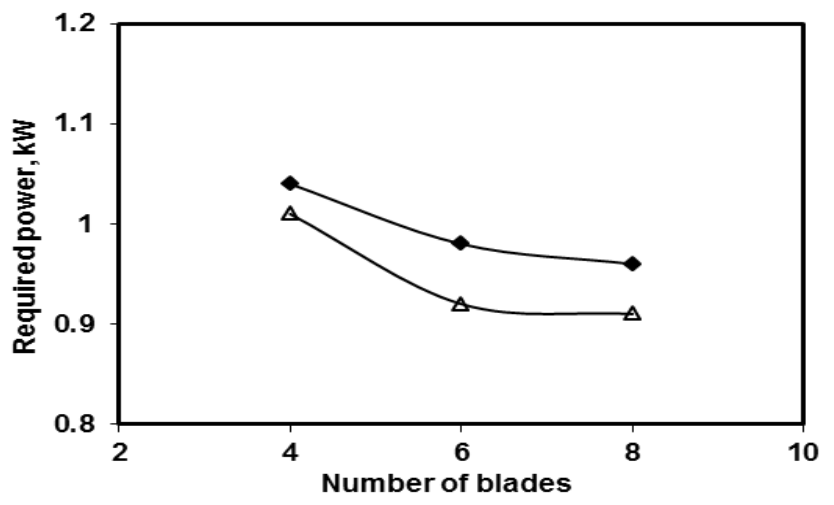

(C) At constant: Rotational speed of $250 \mathrm{rpm}$ and $450 \mathrm{~g}$ meat mass

Fig. 5. Effect of rotational speed, meat mass and number of blades on required power under different holes diameter 
PROCESS ENGINEERING

consumed power, this is agreement with Haack and Schnaeckel (2008).

\section{Energy requirements}

Effect of rotational speed, meat mass and number of blades on energy requirement under different holes diameters were showed in Fig. 6.

With respect to the effect of rotational speed on energy requirements under meat mass of $450 \mathrm{~g}$ and 4 blades, results showed that the lowest value of energy requirement was obtained at rotational speed up to 300 $\mathrm{rpm}$ and then increased. It was 12.59 and $11.54 \mathrm{~kW} . \mathrm{h} / \mathrm{Mg}$ at $300 \mathrm{rpm}$ rotational shaft speed for 4 and $6 \mathrm{~mm}$ die hole diameters, respectively. This can be explained that at low speed, it is needed to high energy rates for cutting meat pieces. While the increase of the speeds above $300 \mathrm{rpm}$, reduced the particles size causing more energy loss by friction.

Concerning the variation of energy rates with different meat masses under rotational speed of $250 \mathrm{rpm}$ and 4 blades, results showed that specific energy requirements for grinding different masses were decreased by increasing meat masses. Energy values were 13.47, 12.84, 12.25 and $11.30 \mathrm{~kW} . \mathrm{h} / \mathrm{Mg}$ for $4 \mathrm{~mm}$ die hole diameter, while $12.38,11.61,11.15$ and $10.19 \mathrm{~kW} . \mathrm{h} / \mathrm{Mg}$ for $6 \mathrm{~mm}$ die hole diameter under 250, 450, 650 and $850 \mathrm{~g}$, respectively. An increase of the required power in cutting the highest meat masse by friction and more time duration was higher than the productivity, so reflected on energy requirement for grinding process.

Energy requirement was influenced by the number of blades in the cutting set. The lowest obtained value of energy requirement was 12.41 and $10.95 \mathrm{~kW} . \mathrm{h} / \mathrm{Mg}$ under using 6 blades for die hole diameters of 4 and 6 $\mathrm{mm}$, respectively. High number of blades impeded the conveying process by blocking more bore holes, this is reflected on reduction in productivity, increase the required power and thereby, the energy requirement was increased. This is an agreement with Irmscher et al. (2013).

Using die hole diameter of $6 \mathrm{~mm}$, the energy was decreased comparing with using $4 \mathrm{~mm}$ hole diameter.

\section{Grinding cost}

Fig. 7 showed the effect of different parameters on grinding cost.

Results revealed the effect of rotational speed on grinding cost under meat mass of $450 \mathrm{~g}$ and using 4 blades that using rotational speed of $300 \mathrm{rpm}$ gave the lowest costs compared to the other speeds. This is return to the 

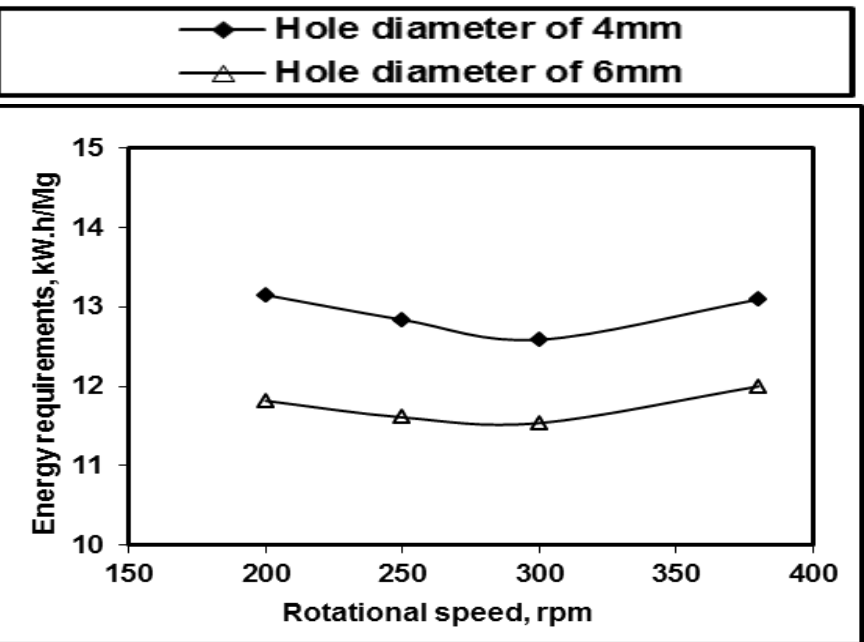

(A) At constant: Meat mass of $450 \mathrm{~g}$ and 4 blades

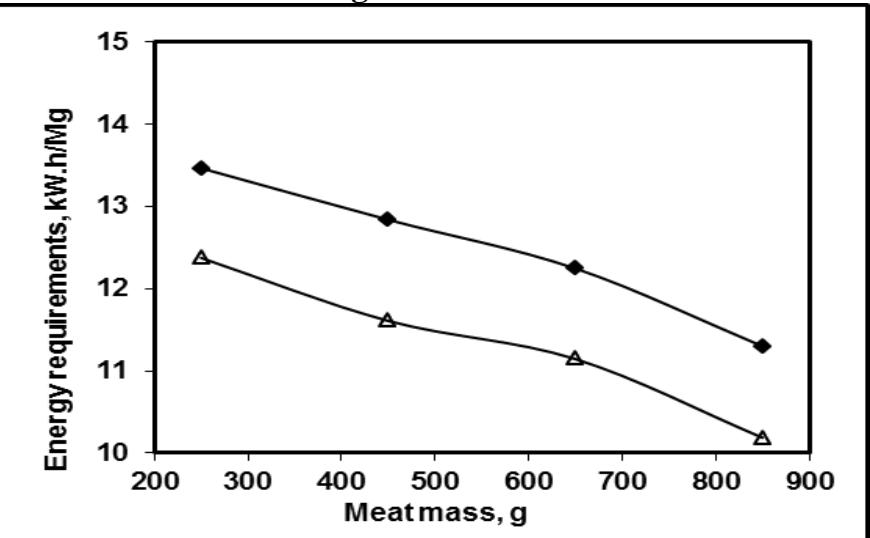

(B) At constant: Rotational speed of $250 \mathrm{rpm}$ and 4 blades

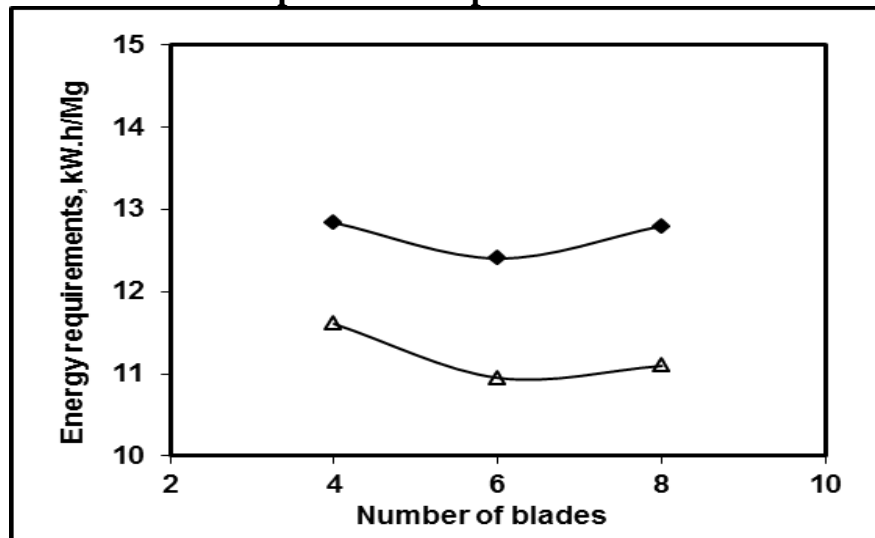

(C) At constant: Rotational speed of $250 \mathrm{rpm}$ and $450 \mathrm{~g}$ meat mass

Fig. 6. Effect of rotational speed, meat mass and number of blades on energy requirement under different holes diameter 


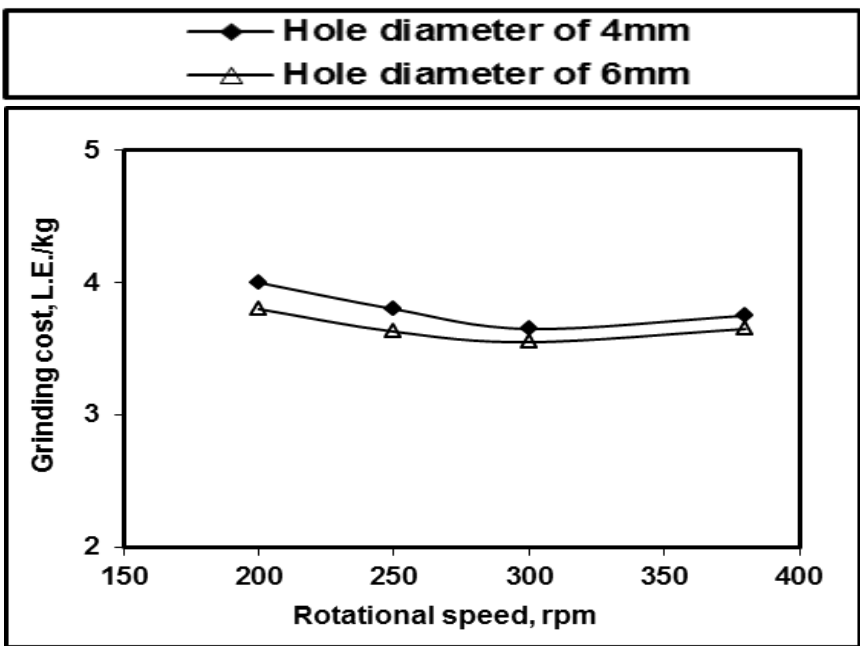

(A) At constant: Meat mass of $450 \mathrm{~g}$ and 4 blades

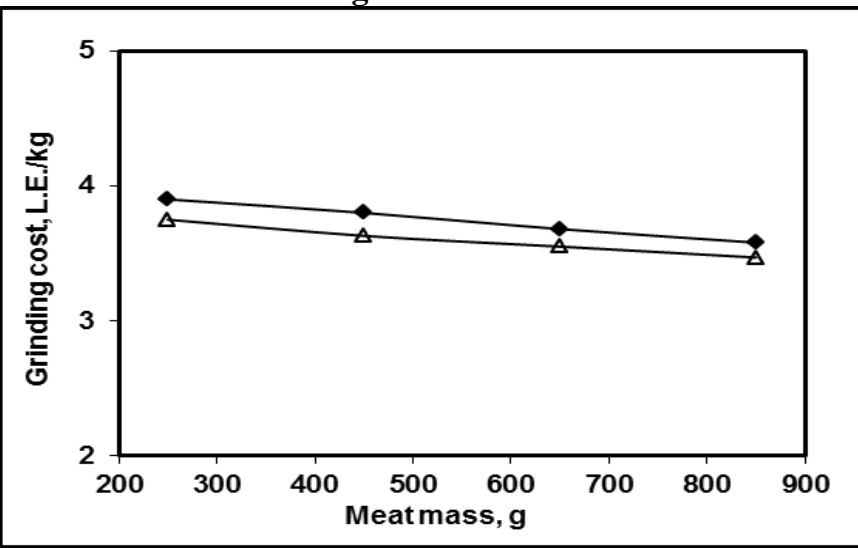

(B) At constant: Rotational speed of $250 \mathrm{rpm}$ and 4 blades

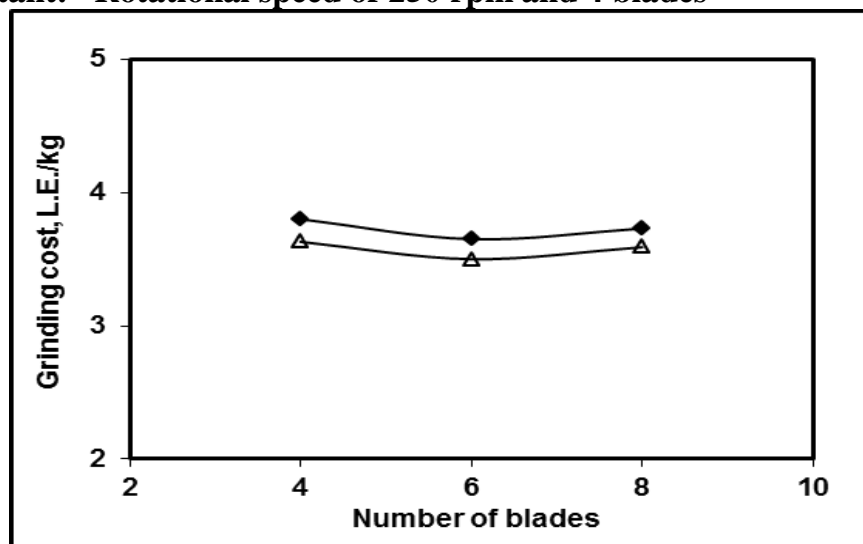

(C) At constant: Rotational speed of $250 \mathrm{rpm}$ and $450 \mathrm{~g}$ meat mass

Fig. 7. Effect of rotational speed, meat mass and number of blades on grinding cost under different holes diameter 
high obtained productivity of grinder under $300 \mathrm{rpm}$, added to that the increase in productivity was higher than the increase in hourly cost. While, the largest values of costs were 4 and 3.8 L.E. $/ \mathrm{kg}$ for 4 and $6 \mathrm{~mm}$ die hole diameters, in that order under using rotational speed of $200 \mathrm{rpm}$. Regarding to the effect of using meat masses under $250 \mathrm{rpm}$ rotational speed and 4 blades, it is evident that grinding cost was reduced with using largest quantities of meat masses. It was $3.9,3.8,3.68$ and 3.58 L.E. $/ \mathrm{kg}$ with $4 \mathrm{~mm}$ die hole diameter, however $3.75,3.63,3.55$ and 3.47 L.E. $/ \mathrm{kg}$ by using $6 \mathrm{~mm}$ hole diameter under different masses of 250, 450, 650 and $850 \mathrm{~g}$, respectively. This may refer to high productivity with increasing meat quantities.

With respect to the effect of blades number on grinding cost under 250 rpm rotational speed and meat mass of $450 \mathrm{~g}$, obtained data clarified that using 6 blades gave the lowest value of grinding cost to be 3.65 and 3.5 L.E./kg for 4 and $6 \mathrm{~mm}$ die hole diameters, respectively. An increase in blade number reduces energy consumption and thus processing costs, according to Irmscher et al. (2013).

Using $4 \mathrm{~mm}$ die hole diameter gave the highest values of grinding costs comparing with $6 \mathrm{~mm}$ die hole diameter, this is attributed to reduction in productivity, more power and energy requirements and thereby, an increase in processing costs.

\section{CONCLUSIONS}

The experimental results reveal that knife geometry affects the quality, energy requirements and production costs. The meat grinder should be operated under the following conditions:

- The grinder shaft must be designed at a $25 \mathrm{~mm}$ diameter.

- Operate the grinder at a rotational speed of $300 \mathrm{rpm}(0.39 \mathrm{~m} / \mathrm{s})$.

- The extruding plate was to be $6 \mathrm{~mm}$ die hole diameter.

- The meat mass should be ranged from 450 to $650 \mathrm{~g}$.

- Using 6 blades in the meat grinder.

\section{REFERENCES}

AOAC (1990).Official Methods of Analysis of the Association Chemists, W. Howrtez (ed.) $15^{\text {th }}$ edn.

Awady, M. N. (1978). Tractor and farm machinery. Txt bk., Col. Agric., Ain Shams Uinv.: 146-167. 
FAO (2012). Food and Agriculture organization of the United Nations. FAO statistics division. FAO state.

http://faostat.fao.org/site/569/DesktopDefault.aspx?PageID=569\#ancor.

Grau, R. (1960). Fleisch und Fleischwaren. 1.Ed., Berlin Verlag A.W. Hayn's Erben: 240 p.

Haack, E. and W. Schnaeckel (2008). Vom Rohstoff zum Feinbrat-Ein Arbeitsgang. Trennsysteme zur Aufwertung Stofflicher Eigenschaften von Fleisch-Teil 2, Fleischwirtschaft, 88 (4): 75-80.

\section{Irmscher, S. B; Z. Bojthe, K. Herrmann, M. Gibis, R. Kohlus and J.} Weiss (2013). Influence of filling conditions on product quality and machine parameters in fermented coarse meat emulsions produced by high shear grinding and vacuum filling. J. of Food Engineering, 117: 316-325.

Khurmi, R. S. (2005). Machines design. Eurasia Publishing House. Ram Nagar, New Delhi. Pp 4-5, 52-57, 568- 571, 716-719, 728-729, 1012-1015.

Kitun, A. V. and V. I. Perednya (2006). Improving the working indices of a grinder-mixer. Traktory i Sel'skokhozyaistvennye Mashiny; 10, 43-44.

Krickmeier, J; W. Schnackel, W. Pongjanyanukul, D. Schnackel and I. Micklisch (2012). Analysis for optimization of the mincing process: Part 2: Distribution of necessary cutting works in dependence of machinery and raw material influences. Fleischwirtschaft; 92: 1, 88-92.

Kurt, G. (1979). Engineering formulas. Third Ed. Mc Graw-Hill book Company. New York St. Lous San Francisco Montreal-Toronto.

Schnackel, W; J. Krickmeier, D. Oktaviani Schnackel and I. Micklisch (2011). Analysis for optimisation of the mincing process: Part 1: Modelling the terms during the disintegration in meat mincers. Fleischwirtschaft; 91: 7, 83-87. 
Soliman, S. N. and M. A. F. Abd El-Maksoud (2001). Performance study of meat chopper. Misr J. Agric. Eng., 18 (1): 131 - 150.

Tkacz, K. (2007). Energy consumption of chosen processes of comminution of meat. Roczniki Instytutu Przemyslu Miesnego i Tluszczowego; 45: 2, 55-61.

\section{الملخص العزبى}

العوامل الهندسية المؤثرة على أداء مفرمة اللحم

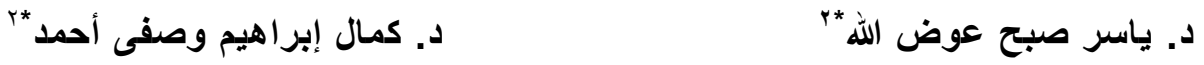
اللحم مصدر الرئيسي للبروتين الحيواني والذي يساعد على بناء خلايا الجسم، إنتاج الكريات

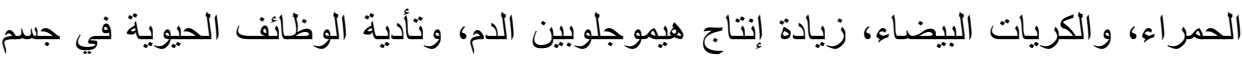

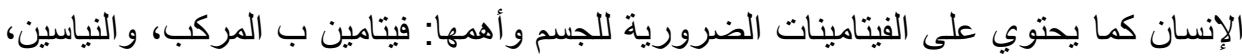

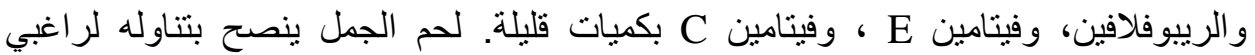

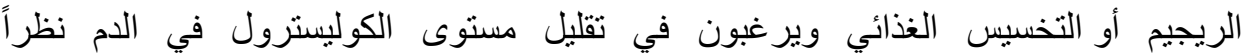

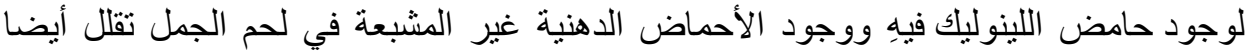

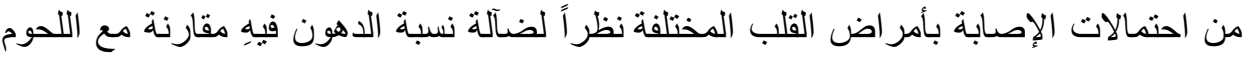

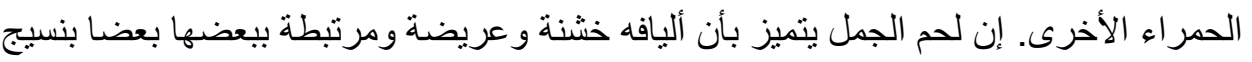

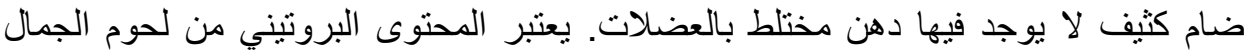

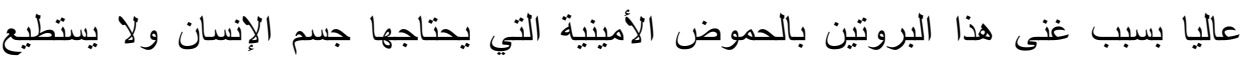
تركيبها. لذلك أجريت دراسة نأثير بعض العو امل الهندسية المؤثرة على فرم لحم الجمل: (كميات مختلفة

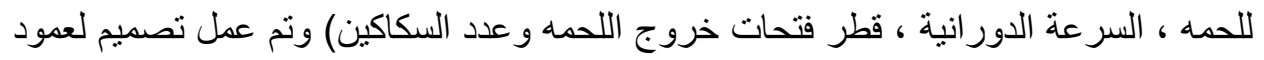

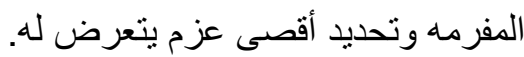

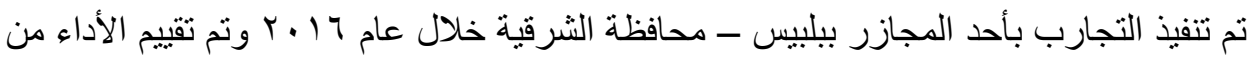
خلال در اسة جودة المنتج المفروم (قدرة الاحتفاظ بالماء ، الانتاجية ، القدرة ، الطاقة المستهلكه

أظهرت النتائج التجريبية أنه للحصول على جودة عاليه للحم المفروم مع تقليل القدرة والطاقة

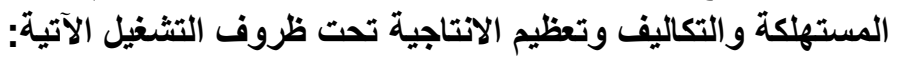

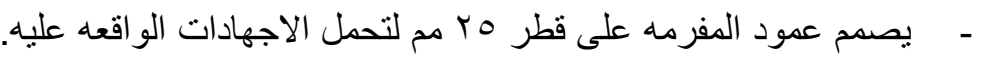

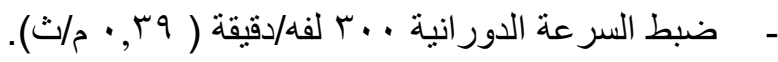

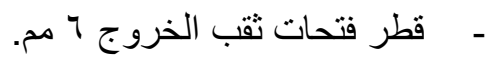

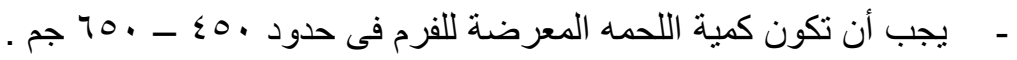
- - - - استخدام عدد 7 سكاكين في عملية الفرم.

" مدرس بقسم الهندسة الزراعية ـ كلية الزراعة - جامعة الزقازيق. 